\title{
Tyrphostins reduce chemotherapy-induced intestinal injury in mice: assessment by a biochemical assay
}

\author{
Y Zlotnik', M Patya', A Vanichkin' and A Novogrodsky*,I \\ 'Felsenstein Medical Research Center, Sackler Faculty of Medicine, Tel Aviv University, Rabin Medical Center, Beilinson Campus, Petah-Tikva 49I00, \\ Israel
}

Intestinal injury that results from chemotherapy belongs to the major factors of dose-limitation in tumour therapy. The tyrphostins AG I7I4 and AGI80I reduce cisplatin and 5-FU-induced small intestinal mucosal damage, using a quantitative biochemical assay. The assay is based on the determination of the enzymatic activity of gamma-glutamyl transpeptidase, a marker of the brush border epithelium of the small intestine.

British Journal of Cancer (2005) 92, 294-297. doi:I0.I038/sj.bjc.6602324 www.bjcancer.com

Published online 18 January 2005

(c) 2005 Cancer Research UK

Keywords: tyrphostins; chemotherapy; chemoprotection; intestinal injury; gamma-glutamyl transpeptidase

Intestinal mucositis is a common complication for a wide variety of anticancer drugs (Khan and Wingard, 2001; Duncan and Grant, 2003).

Clinical trials demonstrated a chemoprotective effect of amifostine (Phan et al, 2001), a granulocyte-macrophage colony stimulating factor (Meropol et al, 1999) and glutamine (Daniele et al, 2001) against chemotherapy-induced intestinal toxicity. We have reported the protective effect of the tyrphostin AG1714 against chemotherapy-induced toxicity without impairing its antitumour efficacy in mice (Novogrodsky et al, 1998). Epithelium injury was assessed by histopathological analysis. Here, we present data on the prevention by the tyrphostins AG1714 and AG1801 of cisplatin and 5-fluorouracil (5-FU)-induced intestinal mucosal damage, using a quantitative biochemical assay. The assay is based on the determination of the enzymatic activity of gamma-glutamyl transpeptidase (GGT), a marker of the brush border epithelium of the small intestine (Tate and Meister, 1981; Ferraris et al, 1992).

\section{MATERIALS AND METHODS}

\section{Mice}

CD1 female mice $(20-25 \mathrm{~g})$ were obtained from Harlan, Jerusalem.

The experimental protocol was approved by the Committee for Care and Use of Laboratory Animals, Rabin Medical CenterBeilinson Campus.

\section{Materials}

AG1714 and AG1801 were synthesised as described (Gazit et al, 1989). Cisplatin, (Sigma, Israel) was dissolved in DMSO (Burdick \&

*Correspondence: Dr A Novogrodsky; E-mail: novog@post.tau.ac.il Received 23 September 2004; accepted 3 October 2004; published online 18 January 2005
Jackson Division, Baxter Healthcare, Muskegon, MI, USA) to obtain a solution of $50 \mathrm{mg} \mathrm{ml}^{-1}$ and was diluted in saline to $1.0 \mathrm{mg} \mathrm{ml}^{-1}$. 5-Fluorouracil (5-FU), $50 \mathrm{mg} \mathrm{ml}^{-1}$, was obtained from ABIC, Israel and diluted in saline. Doxorubicin, $2.0 \mathrm{mg} \mathrm{ml}^{-1}$, was obtained from TEVA, Israel, and diluted in PBS.

\section{Formulations}

For intraperitoneal (i.p.) injections, tyrphostins were dissolved in cremophor (Sigma, Israel)-absolute ethanol $\left(1: 1 \mathrm{w} / \mathrm{w}^{-1}\right)$ and diluted in PBS (without calcium and magnesium). For oral administration, tyrphostins were dissolved in polyethylene glycol (PEG 400) (Sigma, Israel).

\section{Treatment protocol}

Tyrphostins' solutions were freshly prepared immediately before use. They were injected i.p. in a volume of $0.2-0.4 \mathrm{ml} 2 \mathrm{~h}$ prior to the cytotoxic agents, or administered orally in a volume $0.2 \mathrm{ml}, 4 \mathrm{~h}$ prior to the administration of the cytotoxic drugs. Control mice were administered with vehicle solutions.

\section{Gamma-glutamyl transpeptidase assay}

Mice were killed by cervical dislocation.

A segment of the jejunum (approximately $5 \mathrm{~cm}$ ) was isolated, cut and placed into a tube containing ice cold PBS $(2.5 \mathrm{ml})$. The intestinal segments were then flushed with $10 \mathrm{ml}$ of PBS. In total, $2 \times 2 \mathrm{~cm}^{2}$ segments were (for duplication) cut, and placed into $1.0 \mathrm{ml}$ of $1.0 \%$ Triton X-100, $0.15 \mathrm{M} \mathrm{NaCl}, 100 \mathrm{~mm}$ Tris, $\mathrm{pH} 8.0$ (Tris-Triton buffer) and stirred for $2 \mathrm{~min}$. After $30 \mathrm{~min}$ in ice, the tubes were centrifuged and the supernatants were diluted $1: 1$ with Tris-Triton buffer. A measure of $0.02 \mathrm{ml}$ were added to a reaction mixture containing: $0.3 \mathrm{ml}$ of $100 \mathrm{~mm}$ glycyl-glycine, $\mathrm{pH} 8.0$, $0.08 \mathrm{ml}$ Tris-Triton buffer, $0.5 \mathrm{ml}$ of $5 \mathrm{mM}$ gamma-glutamyl- $p$ nitroanilide (dissolved in $100 \mathrm{~mm}$ Tris, $\mathrm{pH}$ 8.0) (final volume, 
$0.9 \mathrm{ml}$ ). All the reagents for GGT determination were obtained from Sigma, Israel.

After incubation for $10 \mathrm{~min}$ in a shaking water bath at $37^{\circ} \mathrm{C}$, the reaction was stopped by placing the tubes in ice and adding $0.1 \mathrm{ml}$ of glacial acetic acid. After centrifugation, supernatants were read at $405 \mathrm{~nm}$ (ELISA). Results were expressed as units of GGT activity per $\mathrm{cm}$ of jejunum. One unit is defined as GGT activity, which releases $1.0 \mu \mathrm{mol}$ of $p$-nitroaniline in $1 \mathrm{~h}$.

\section{Statistical analysis}

The results were expressed as means \pm s.e.m. Differences among the treatment groups were evaluated using the two-tailed Student's $t$-test. $P$-values of $<0.05$ were considered statistically significant.

\section{RESULTS}

Figure 1 illustrates the chemical structure of AG1714 and AG1801. As depicted in Figure 2, cisplatin $\left(10 \mathrm{mg} \mathrm{kg}^{-1}\right)$, injected intraperitoneally (i.p.), markedly reduced the content of the GGT in the small intestine jejunum mucosa of mice, as determined 4 days later. Administration of AG1714 $\left(20 \mathrm{mg} \mathrm{kg}^{-1}\right.$ i.p. $) 2 \mathrm{~h}$ prior to injection of cisplatin, abrogated the cisplatin effect by more than two-fold. AG1801 is a structural analogue of AG1714 that shares with it chemoprotective properties such as reduction of chemotherapy-induced mortality and myelosuppression. AG1801 is effective at a lower dose compared to AG1714. Maximal chemoprotective effect of the tyrphostins, administered orally, was attained at higher doses compared to i.p. administration (unpublished observations).

AG1801 is also effective in attenuating chemotherapy-induced small intestinal injury as assessed by determination of GGT activity in the jejunum mucosa.

As depicted in Figure 3A, AG1801 (0.5-1.0 mg kg-1), administered intraperitoneally $2 \mathrm{~h}$ prior to cisplatin, abrogated the cisplatin $\left(10 \mathrm{mg} \mathrm{kg}^{-1}\right.$, i.p.) effect by almost two-fold. Oral administration of AG1801 (50 mg kg$\left.)^{-1}\right), 4 \mathrm{~h}$ prior to cisplatin, almost completely prevented cisplatin $\left(10 \mathrm{mg} \mathrm{kg}^{-1}\right.$, i.p.)-induced small intestinal injury (Figure 3B).

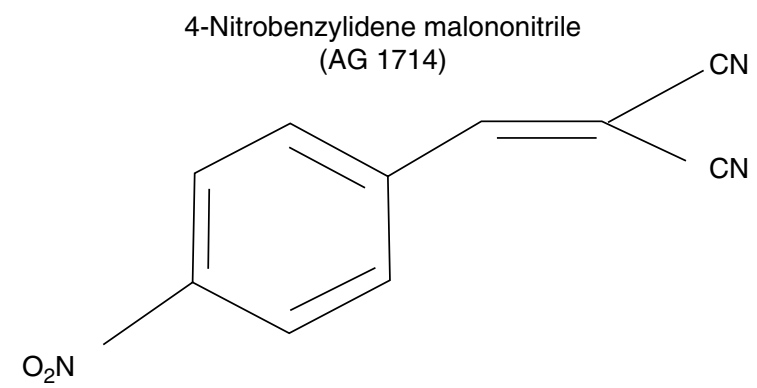

2-Cyano-3-(4-nitrophenyl)- $N$-(phenylmethyl)-2-propenamide (AG 1801)

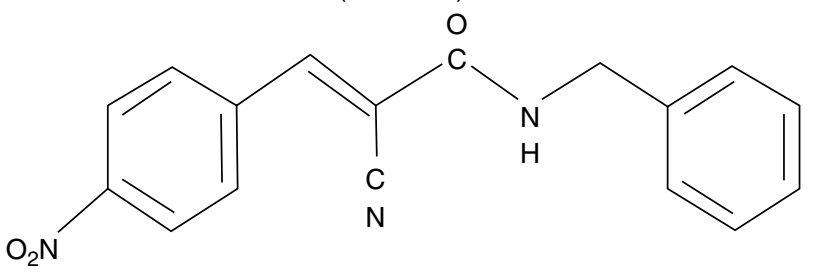

Figure I Structure of AGI7|4 and AGI80I.

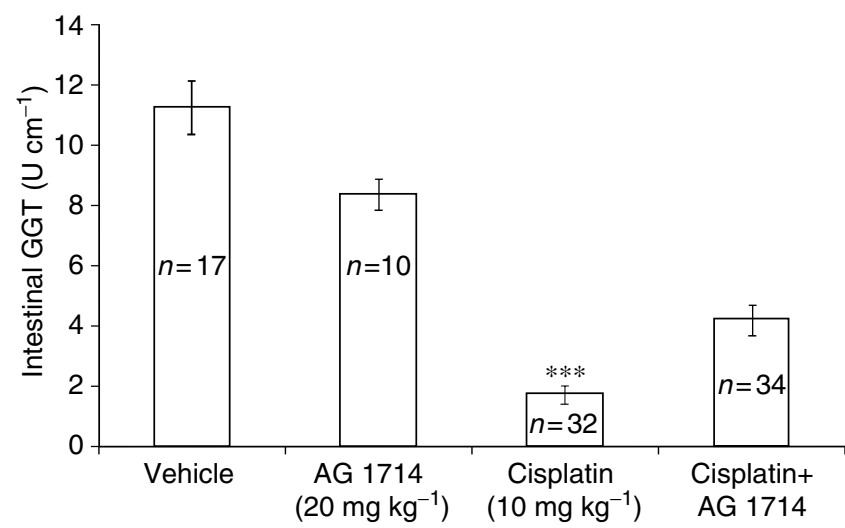

Figure 2 Effect of $A G I 7 / 4$ (i.p.) on cisplatin-induced reduction of intestinal GGT. CDI mice were injected (i.p.) with $A G|7| 4,2 \mathrm{~h}$ prior to injection (i.p.) of cisplatin. Mice were killed 4 days after cisplatin administration and small intestinal GGT was determined as described in Materials and Methods. The number of mice $(n)$ in each experimental group is depicted in the figure. Figure includes data from five different experiments. Results are expressed as units of GGT activity per I cm of small intestinal jejunum \pm s.e.m. $* * * P<0.001$, mice treated with cisplatin + AGI7I4 vs cisplatin alone.

AG1801, administered orally was also effective in reducing 5-FUinduced small intestinal injury. Oral administration of AG1801, $4 \mathrm{~h}$ prior to $5-\mathrm{FU}$, markedly reduced $5-\mathrm{FU}\left(200 \mathrm{mg} \mathrm{kg}^{-1}\right.$, i.p.)-induced small intestinal injury (Figure 4).

\section{DISCUSSION}

Using the quantitative biochemical GGT method, we demonstrated the protective effect of the tyrphostins AG1714 and AG1801 against chemotherapy-induced small intestinal injury. We have previously demonstrated the protective effect of AG1714 against cisplatin induced small intestinal toxicity, using histological analysis (Novogrodsky et al, 1998). The biochemical method supplements histological analysis, and has the advantage of providing an objective quantitative assessment of the integrity of the mucosa in a large segment of the intestine.

Oral administration of the tyrphostins seems to be more effective than the intraperitoneal route. This may be due to the direct access of the tyrphostins to the intestinal mucosa.

Chemotherapeutic agents induce intestinal toxicity by an apoptosis-mediated mechanism (Potten et al, 1997; Papaconstantinou et al, 2001).

We have previously (Novogrodsky et al, 1998; Vanichkin et al, 2002) postulated that the chemoprotective effect of the tyrphostins is attributed to their ability to selectively inhibit the induction of apoptosis in normal cells but not in cancer cells.

The molecular targets of AG1714 and AG1801 are unknown. These compounds are structurally related to the tyrphostin family that selectively inhibits protein tyrosine kinases (Levitzki and Gazit, 1995). Inhibitors of tyrosine kinases were shown to modulate apoptosis induced by a variety of agents in different cell types (Uckun et al, 1992; Bergamaschi et al, 1993; Liu et al, 1994; Ji et al, 1995). It should be noted, however, that AG1714 and AG1801 are not derivatives of hydroxylbenzylidene malononitrile like most of the reported tyrosine kinase inhibitors of the tyrphostin family. Thus, it is not at all certain that the effect of AG1714 and AG1801 reported here is related to the inhibition of protein tyrosine kinases(s). Moreover, as noted above, these compounds are effective upon administration $2-4 \mathrm{~h}$ prior to chemotherapy. The i.p. $\left(10 \mathrm{mg} \mathrm{kg}^{-1}\right)$ bioavailability of AG1801 was calculated to be about $26 \%$ and the oral $\left(20 \mathrm{mg} \mathrm{kg}^{-1}\right)$ bioavail- 

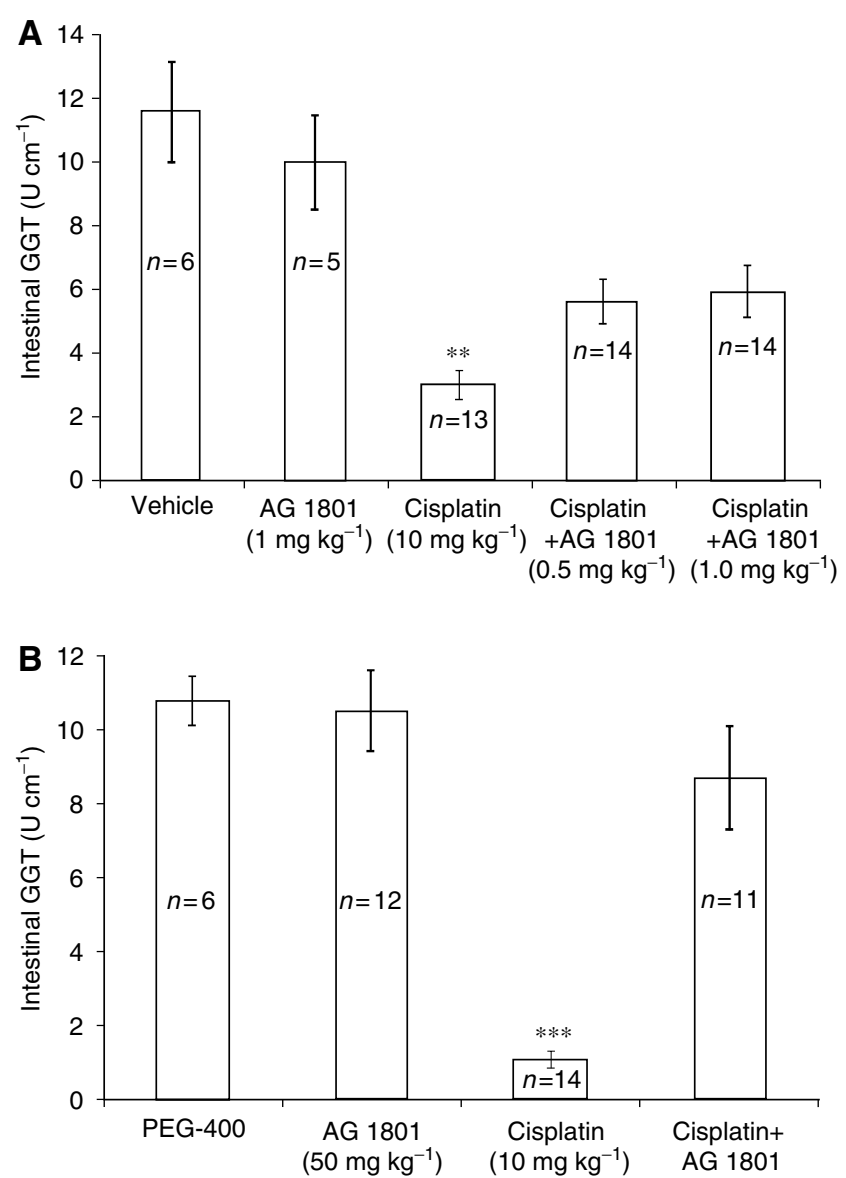

Figure 3 (A) Effect of $A G \mid 80$ I (i.p.) on cisplatin-induced reduction of intestinal GGT. Experimental conditions were similar to those outlined for Figure I, except that AGI80 I (at the doses indicated, i.p.) was used. Figure includes data from three different experiments. ${ }^{*} * P<0.01$, mice treated with cisplatin + AGI80I vs cisplatin alone. (B) Effect of AGI80I, administered orally, on cisplatin-induced reduction of intestinal GGT. Mice were injected (i.p.) with cisplatin $\left(10 \mathrm{mg} \mathrm{kg}^{-1}\right), 4 \mathrm{~h}$ after oral administration (by an intragastric tube) of AGI80I $\left(50 \mathrm{mg} \mathrm{kg}^{-1}\right)$. Intestinal GGT was determined 4 days after cisplatin administration. Figure includes data from three different experiments. $* * * * P<0.00 I$, mice treated with cisplatin $+A G|80|$ vs cisplatin alone.

ability was calculated to be $21 \%$. However, AG1801 is cleared rapidly from the blood ( $T_{1 / 2}$, is less than $\left.10 \mathrm{~min}\right)$. Hence, at the time of the administration of chemotherapy, the blood level of AG1801 may be very low. AG1801 may elicit its effect by providing a signal, rendering the cell resistant to the induction of apoptotic

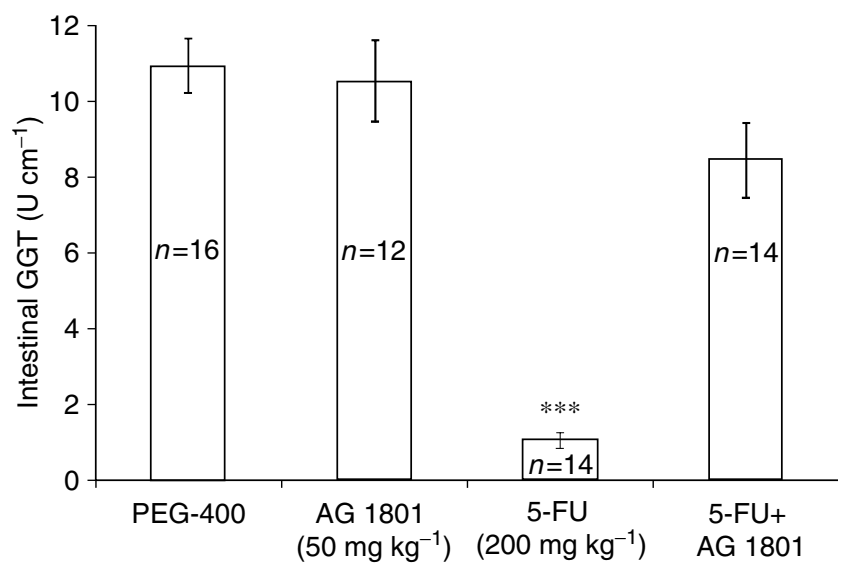

Figure 4 Effect of $A G I 80 I$ (administered orally) on 5-FU-induced reduction of intestinal GGT. Mice were injected (i.p.) with 5-FU $\left(200 \mathrm{mg} \mathrm{kg}^{-1}\right) 4 \mathrm{~h}$ after oral administration of $\mathrm{AGI} 80 \mathrm{l}\left(50 \mathrm{mg} \mathrm{kg}^{-1}\right)$. Intestinal GGT was determined 4 days after cisplatin administration. Figure includes data from three different experiments. $* * * *<0.00$ I, mice treated with $5-\mathrm{FU}+\mathrm{AGI} 80 \mathrm{I}$ vs $5-\mathrm{FU}$ alone.

injury. It is also possible that a degradation product of AG1801 rather than the native compound elicits the biological effect.

The study reported here was confined to biochemical monitoring of acute small intestinal injury in the mouse induced by chemotherapy. The GGT method is not suitable for assessment of large intestinal damage due to the low content of GGT. The applicability of this method to other species or other types of intestinal damage, such as those associated with inflammatory processes, requires further investigation. In this context, it should be noted that GGT in different cell types is subject to phenotypic alterations induced by different agents (Novogrodsky et al, 1976; Wasserman et al, 1987; Sidi et al, 1988).

It is very difficult to quantitatively assess the sensitivity of biochemical GGT assay in comparison to the histological assay. However, The intestinal injury induced by chemotherapy is quite often nonhomogenous and therefore the biochemical assay that analyses a long segment of the intestine (centimeters) is superior to the histological assay that analyses a very small segment (microns).

\section{ACKNOWLEDGEMENTS}

This study was supported by NOTOX Ltd., Israel. We are grateful to Mrs S Dominitz for editorial assistance.

\section{REFERENCES}

Bergamaschi G, Rosti V, Danova M, Ponchio L, Lucotti C, Cazzola M (1993) Inhibitors of tyrosine phosphorylation induced apoptosis in human leukemic cell lines. Leukemia 7: 2012-2018

Duncan M, Grant G (2003) Oral and intestinal mucositis - causes and possible treatments. Aliment Pharmacol Ther 18: 853-874

Daniele B, Perrone F, Gallo C, Pignata S, De Martino S, De Vivo R, Barletta E, Tambaro R, Abbiati R, D’Agostino L (2001) Oral glutamine in the prevention of fluorouracil induced intestinal toxicity: a double blind, placebo controlled, randomised trial. Gut 48: $28-33$

Ferraris RP, Villenas SA, Diamond J (1992) Regulation of brush-border enzyme activities and enterocyte migration rates in mouse small intestine. Am J Physiol 262: G1047-G1059

Gazit A, Yaish P, Gilon C, Levitzki A (1989) Tyrphostins I: synthesis and biological activity of protein tyrosine kinase inhibitors. J Med Chem 32: $2344-2352$

Ji L, Zhang G, Hirabayashi Y (1995) Inhibition of tumor necrosis $\gamma$ and ceramide-induced internucleosomal DNA fragmentation by herbimycin A in U937 cells. Biochem Biophys Res Commun 212: 640-647

Khan SA, Wingard JR (2001) Infection and mucosal injury in cancer treatment. J Natl Cancer Inst Monogr 29: 31 -36

Levitzki A, Gazit A (1995) Tyrosine kinase inhibition: an approach to drug development. Science 267: $1782-1788$

Liu Y, Bhalla K, Hill C, Priest DG (1994) Evidence for involvement of tyrosine phosphorylation in taxol-induced apoptosis in human ovarian tumor cell line. Biochem Pharmacol 48: 1265-1272 
Meropol NJ, Rustum YM, Creaven PJ, Blumenson LE (1999) Phase I and pharmacokinetic study of weekly 5-fluorouracil administered with granulocyte-macrophage colony-stimulating factor and high-dose leucovorin: a potential role for growth factor as mucosal protectant. Cancer Invest 17: 1-9

Novogrodsky A, Tate SS, Meister A (1976) $\gamma$-Glutamyl transpeptidase, a lymphoid cell-surface marker: relationship to blastogenesis, differentiation and neoplasia. Proc Natl Acad Sci 73: 2414-2418

Novogrodsky A, Weisspapir M, Patya M, Meshorer A, Vanichkin A (1998) Tyrphostin 4-nitrobenzylidene malononitrile reduces chemotherapy toxicity without impairing efficacy. Cancer Res 58: 2397-2403

Papaconstantinou HT, Xie C, Zhang W, Ansari NH, Hellmich MR, Townsend Jr CM, Ko TC (2001) The role of caspases in methotrexateinduced gastrointestinal toxicity. Surgery 130: 859-865

Phan T, Crane C, Jan N, Vrdoljak E, Milas L, Mason K (2001) WR-2721 reduces intestinal toxicity from concurrent gemcitabine and radiation treatment. Int J Gastrointest Cancer 29: 19-24

Potten CS, Wilson JW, Booth C (1997 Regulation and significance of apoptosis in the stem cells of the gastrointestinal epithelium. Stem Cells 15: $82-93$
Sidi Y, Panet C, Wasserman L, Cyjon A, Novogrodsky A, Nordenberg J (1988) Growth inhibition and induction of phenotypic alterations in MCF-7 breast cancer cells by an IMP dehydrogenase inhibitor. $\mathrm{Br}$ J Cancer 58: $61-63$

Tate SS, Meister A (1981) Gamma-glutamyl transpeptidase: catalytic, structural and functional aspects. Mol Cell Biochem; 39: $357-368$

Uckun FM, Tuel-Ahlgren L, Song CW, Waddick K, Myers DE, Kirihara J, Ledbetter JA, Schieven GL (1992) Ionizing radiation stimulates unidentified tyrosine-specific protein kinases in human B-lymphocyte precursors, triggering apoptosis and clonogenic cell death. Proc Natl Acad Sci USA 89: 9005 -9009

Vanichkin A, Patya M, Lagovsky I, Meshorer A, Novogrodsky A (2002) 4-Nitrobenzylidene malononitrile reduces apoptosis-mediated acute liver injury in mice. $J$ Hepatol 36: $631-636$

Wasserman L, Nordenberg J, Beery E, Deutsch AA, Novogrodsky A (1987) Differential effects of sodium butyrate and dimethylsulfoxide on $\gamma$-glutamyl transpeptidase and alkaline phosphatase activites in MCF-7 breast cancer cells. Exp Cell Biol 55: $189-193$ 